\title{
Jurisdiction, inscription, and state formation: administrative modernism and knowledge regimes
}

\author{
Chandra Mukerji
}

Published online: 24 February 2011

(C) The Author(s) 2011. This article is published with open access at Springerlink.com

\begin{abstract}
In seventeenth-century France, Colbert built a more effective state administration not by rationalizing state offices but by using public documents to increase the government's intellectual capacity to exercise logistical power and engage in territorial governance. This pattern calls into question Weber's model of the genesis of "modern officialdom," suggesting that its source was not social rationalization, but rather the identification and management of expertise. Colbert recruited into government nascent technocrats with knowledge useful to territorial politics, using contracts and other documents to limit their independence and subordinate them to patrimonial authorities. They exercised specific duties and impersonal powers in jurisdictional areas - much like modern technocrats. Their expertise enhanced the intellectual capacity of the administration to exercise territorial power and made the state less dependent on patrimonial clienteles without challenging the patrimonial culture of power/knowledge.
\end{abstract}

Keywords Weber B Bureaucratic files · Power/knowledge Political networks · Distributed cognition $\cdot$ Public documents $\cdot$ Roman numerals

We know from Weber et al. (1978) the importance of bureaucratic files to modern forms of administration, but we know relatively little historically about how public documents were developed, written, circulated, and used for political effect, or about the types of regimes they supported. We also know from Foucault (1966, 1977a, b; Foucault and Gordon 1980) the importance of the circulation of knowledges to practices of power, but we are only beginning to understand how the design of files and movement of information contributed to modern governments. Becker and Clark (2001) have made a case for studying these "little tools of knowledge;" Porter (1995) has demonstrated the importance of numbers in bureaucratic paperwork; and Patrick

C. Mukerji $(\square)$

Department of Communication, University of California San Diego, 9500 Gilman Drive, La Jolla, CA 92093-0503, USA

e-mail: cmukerji@weber.ucsd.edu 
Joyce (2009) has shown the complex social ties in the Raj woven through the archiving and circulation of official documents. This article contributes to this program of research, showing the program's value for explaining administrative modernization in late seventeenth-century France.

Focusing on how official documents were designed, developed, collected, and circulated under Jean-Baptiste Colbert, I demonstrate that paperwork was used to increase the administration's access to the expertise needed for territorial governance. It carried information about infrastructural and land-management projects, specified contracted responsibilities of "experts" for state enterprises, and made available to the administration official documents about land, including papers formerly controlled by nobles. These activities expanded the intellectual capacity of the administration to control the king's lands and engage in territorial politics. The effect was to reduce the relative autonomy of nobles as public officials and landholders, but without challenging nobility as the fundamental principle of power. The standing of ruling elites as officials remained unchanged because the new contracted agents of the administration were kept distinct and subordinate, fulfilling prescribed duties and prevented from acting independently of their jurisdictions.

Bringing more experts without high rank to administrative projects during the Ancien Régime could augment Colbert's ability to exercise power because the process brought non-conventional patterns of thinking into government. As Mannheim et al. (1952, pp. 12-87, 97-153) and Haraway (1989, pp. 26-58) have argued, albeit in different ways, knowledges are social products that are distributed differentially across social strata, leading groups and institutions (including state administrations) to create limited intellectual cultures. New knowledge entering an established political culture could be a dangerous and powerful tool of change precisely because novel forms of expertise would be foreign to entrenched political elites, tipping the balance of power away from them and in a direction that would be hard for them to follow.

On the other hand, as Nietzsche (1990, pp. 147-190) has argued, the authority to know (particularly the moral authority to know) is also generally stratified by rank. Those with the standing to govern have a moral basis for their powers that defines them as superior. Bringing knowledge from subjugated populations into government would necessarily carry a potential threat to the social foundations of political legitimacy. Power and knowledge are supposed to be aligned, so using knowledge from those without power would present a problem of political administration.

Colbert solved the problem in seventeenth-century France by separating the use of technical knowledge in politics from the social and moral authority to know, subordinating those with worldly knowledge to the superior authority of elites. Exercising political judgment remained a matter of nobility (of character or blood), while territorial politics was pursued by experts without independent credibility or standing. ${ }^{1}$ The latter became impersonal, contractual agents of the administration

\footnotetext{
${ }^{1}$ Colbert was not entirely able to contain the logistical powers unleashed this way, and could not entirely suppress those who engaged in engineering for the state, so the social order he tried to enforce had more contradictions than this model suggests (Mukerji 2010a, b). But what Colbert tried to do nonetheless resulted in a modernization of the administration.
} 
who circulated through government projects under the supervisory eyes of social superiors.

The experts of low standing were mainly people who engaged in finance or worked the earth. They were entrepreneurs, low-status engineers and builders, peasants and artisans. Their expertise was experiential more than formal, and this gave their knowledge low standing, too. They were not seen as independently worthy of power and capable of wielding it wisely. They had useful knowledge, of course, but not the social prerequisites for the authority to know. So, they were given contracts rather than offices, duties rather than seats of power, and they were supervised using dispassionate measures of adequacy. By this mechanism, the administration began to be filled with Weberian "servants of standing" or modern bureaucrats with contingent, jurisdictional powers (Weber et al. 1978, p. 957), carrying into public administration new tactics of power/knowledge (Mukerji 2010a).

Knowledge of French land traditionally lay in official documents held by noble families, defining lines of inheritance of domains, and providing data about usage rights and the physical condition of the land. Held privately or in regional tribunals or governing bodies, these papers served as tools of noble autonomy and information control. So, when Colbert collected these papers for the administration, he endowed the administration with a form of political intelligence about the kingdom that not only added to its capacity for territorial governance, but undercut the autonomy of regional governments. Regional and personal records acquired for the administration combined with new documents commissioned by Colbert made public records increasingly into tools of state power rather than noble independence (Mukerji 2007a, 2010a).

The primary organizational problem for Colbert was determining how to bring non-nobles into public service without delegitimating the government, and how to secure noble archives without alienating ruling elites. The solution was paperwork: contracting lower-status state agents to exercise highly circumscribed and supervised powers, and subjugating them on paper to the supervision of men of rank. Contractual practices defined low-status experts as temporary agents rather than permanent officials, and the documents used for their supervision kept the accumulation and flow of paperwork mainly a noble activity. In this way, the administration created impersonal practices of governance to constitute a new knowledge regime, using a profusion of paperwork to manage the risks and sustain the legitimacy of the government (Mukerji 2007a).

The new administrative practices of power were not formed around a rational bureaucracy, but rather by the circulation of papers and contracted expertise. The new knowledge regime created a novel political capacity in the state, but surprisingly, did not entail a revolution in the fundamental system of power/ knowledge in France (nobility remained the foundation of officialdom). Contractual projects of territorial governance defined a distinct kind of service to the state: a form of impersonal, material obligation, and anonymous technical work. Administration by contract and technical practice was not only orthogonal to the personal patron-client relations of patrimonialism, but also was regulatory (or organized around written instructions, specifications, and rules of conduct). Contracted agents of the state had only the powers needed for their prescribed duties and were assessed 
in relation to contractual obligations. They served government in narrow and contingent ways quite unlike traditional officials who exercised autonomous powers. Still, the new agents also had profound effects on French life and state power. They used their material competencies to transform France with territorial projects that were much more consequential than expected-both politically and socially (Mukerji 2010b).

In managing territorial projects impersonally through paperwork, Colbert helped to maintain the social distance and sustain the sense of moral distrust between traditional officials and new agents of the administration, securing the technocratic capacity for territorial politics as an unrivaled asset of the administration. The contracts also set up a supervisory structure for territorial projects that was in principle both hierarchical and functionally dispassionate - more like that of a modern state. With these distinctive practices of territorial power/knowledge, the administration became more effective in realizing its programs, and extending state powers over more areas of French life.

The case of French state formation both ratifies and counters Weber's model of the genesis of "modern officialdom," (1978, pp. 956-998) suggesting that a shift in knowledge regimes that included files and archives was more important than social rationalization (Mukerji 2010a). The moral authority of the nobility was not challenged by the new emphasis on natural knowledge, but its power was nonetheless eroded by political territoriality. Ruling elites lost land for state projects and could not easily engage in large-scale territorial ones on their own. Also, their personal ties of mutual affection and obligation - the bases of patrimonial powercould not assure good technical outcomes in programs of military or civil engineering. Collectively cultivated technical expertise by low-status actors became a potent source of state-based and state-organized power.

Colbert has been criticized for not streamlining the bureaucracy, and producing instead what is often characterized as an awkward and inefficient dual system of government, leaving extant legal and tax officials undisturbed, while appointing new officials like provincial intendants loyal to the king. ${ }^{2}$ This view is easy to maintain while studying mainly gentlemen and elite clienteles, and paying less attention to those of lower rank and technical expertise who entered the administration (Beik 1985, pp. 59-148; Kettering 1986, pp. 68-97; Mousnier 1979, pp. 48-57, 214-250). But it does not capture the important organizational changes of government in this period.

As I have argued elsewhere (Mukerji 2009a, pp. 15-35, 203-227, 2010a), the modern French state that developed in the late seventeenth century was primarily a product of territorial politics and the use of logistical power to bypass or undermine the patrimonial networks that had previously both defined and limited the power of the king. Here I want to show how territorial politics led to or entailed administrative modernization as a mean for assembling the necessary intellectual competence for

\footnotetext{
${ }^{2}$ For his part, Colbert tried to rationalize the bureaucracy, but was not able to reform either tax collection or the legal system because most of those who held important offices were men of high rank. The minister of the army, Louvois, was more successful with the military, but the rationalization of ranks in the army did not effectively change governance, just the practice of war (Lynn 1997).
} 
territorial governance, and for managing experts without disturbing the principle of patrimonial authority.

Official documents used for this end did not simply serve as immutable mobiles for the state (Latour 1987, pp. 226-230), carrying policy and technical information from Versailles to the provinces and back. They served more critically in the formation of more impersonal networks in government, connecting people through inscriptions to territorial projects, and creating a system of impersonal rule.

Constrained and empowered in the minister's knowledge regime, Colbert's new agents became Weber et al.'s (1978, p. 957) “servants" of standing with contingent authority in relation to prescribed duties. ${ }^{3}$ Like Ottoman officials who were appointed to high office because they were slaves and could develop no independent following (Meeker 2002, pp. 144-151), low-status state agents could be given substantial powers of territorial governance because they had few avenues for pursuing legitimate power outside their contracted roles. They made their knowledge powerful by making it available to the state, and they exercised logistical power within the confines of their prescribed jurisdictions. In this way, Colbert's agents/ experts became more like modern bureaucrats without being inserted into a rational bureaucracy.

\section{Vernacular roman numerals as social indicators}

To consider more precisely how documents figured into the modernization of the French administration, I want to focus on a relatively rare system of inscription that was used in important public documents: vernacular roman numerals. ${ }^{4}$ Numerical inscriptions might seem of minor importance to politics, but standing for traditional, legal authority and also the heritage of ancient Rome, these roman numerals using French units of counting marked and conveyed moral political authority and timeless power. Employed in legal documents, vernacular roman numerals represented the authority of law that ruling elites still wielded, and also the tradition of Roman law in French jurisprudence. Used in dates, they pointed to the Roman roots of French ways of measuring time and to the interest of classical elites in natural knowledge (Duncan 1998, p. 46; Long 2001, pp. 16-45). As part of classical learning used by the Church and nobility alike, they stood for the moral foundations of hierarchical authority itself, as well as the legal foundations of noble rule. In

\footnotetext{
$\overline{3}$ In his discussion of bureaucracy, Weber points to activities, authority, and qualifications as elements of modern, jurisdictional power. All of these were problematic for state agents working on projects of political territoriality in seventeenth-century France, and all were addressed with official documents. The men of less-than-noble standing who served Louis XIV in the administration could not derive their authority from personal rank (the practice of noble office holders), so it was asserted instead with papers that marked them as qualified with signs of office. Edicts of the king, contracts made with the state, judicial decisions relating to those contracts, and letters and instructions from Colbert all helped to define the activities of administrative officials, too, both their duties and the criteria for determining the proper exercise of those duties. In these ways, the jurisdictional power and technical expertise of state agents were both asserted and circumscribed with paperwork.

${ }^{4}$ I want to thank Steve Shapin for encouraging me to study these numbers, and to thank Ted Porter, Cheryl McWatters, and Yannick Lemarchand for help in doing it.
} 
seventeenth-century political documents, they were surprisingly sensitive indicators of shifts in authority during the period of state formation.

Before widespread adoption of Hindu-Arabic numerals, roman numerals were ubiquitous in Europe (Lemarchand 2010). A French variant of the system started to develop in the Middle Ages, and was already used in a fourteenth-century account book written by two merchants from Montalban, the Bonis brothers. They used roman numerals written to express French ways of counting in listing the costs and obligations entailed in their transactions (Forestié 1893).

These "vernacular roman numerals" were typical in accounts in France and parts of England, but not in Spain, Italy, Germany, Scotland, the Netherlands, and other parts of England, where people wrote roman numerals differently. The French system used base twenty for some numbers, writing 90 as "iiiixx et x" or four twenties plus ten. The other European system used base ten, 90 having its own symbol-either "xC" or "lxxxx." Base 20 was common in French vernacular counting, and was sometimes used in English: the "score" that Lincoln used in his famous speech ("four score and seven years ago..."). But base ten remained the norm elsewhere. That is why the roman numerals using base 20 came to be called "French"- even though this type of numerical notation was often used in England, too (Lemarchand 2010).

By the early sixteenth century, Hindu-Arabic numbers were widely adopted for accounting purposes, but vernacular roman numerals still had specific uses. They were embraced by humanists and employed routinely for calendars, clocks, coins, and the title pages of books. ${ }^{5}$ French-vernacular roman numerals continued to be used in official documents, too, to distinguish legal issues and political authority from mundane matters (Lemarchand 2010). We can see this in Les comptes des bâtiments $d u$ roi for François I ${ }^{\mathrm{e}}$ (Laborde and Guiffrey 1877, pp. 341-368). These household accounts for the king were written with vernacular roman numerals, distinguishing activities of the royal household from mundane forms of life. They pointed to the divide between noble and worldly economic practices that was evident in period tax policies and treatment of debt. ${ }^{6}$

Toward the end of the sixteenth century, even this tradition of writing accounts in vernacular roman numerals was eroding, though, and Les comptes des batiments $d u$ roi started to be written with Hindu-Arabic numbers. ${ }^{7}$ But still official documents were routinely required to be written with vernacular roman numerals (Lemarchand 2010). We can see the results in a sixteenth-century manuscript written by Nicolas de Nicolay for Catherine de Medici, describing the history and patterns of life in the city of Lyon. The manuscript used both Hindu-Arabic and vernacular roman numerals, but each in a different part of the text. In describing the commercial

\footnotetext{
${ }^{5}$ In a register of printed calendars, the kalendrier des bergers from 1503 to 1506, for example, Frenchbased roman numerals were used for the listings of publication dates: "Finit le compost et kalendrier des bergers Imprime a Paris par Guiot marchant demourant au champ gaillart derriere le college de nauarre Lan: M.ccc.iiiixx et xiii. Le xviii jour Davril” (Pynson et al. 1892).

${ }^{6}$ It was just the kind of separation implied by the use of roman numerals for naming successions of kings and popes.

${ }^{7}$ Perhaps the growth of capitalist trade and its increased salience to politics made a difference, but whatever the case, payments for the king's household began to be treated more as financial transactions than matters of law.
} 
activity of the city, Nicolay used Hindu-Arabic numbers, but in writing about official spending and taxation, he used vernacular roman numerals (Nicolay 1881, p. 204). ${ }^{8}$

$\begin{array}{ll}\text { Des receptes non muable la somme de } & \text { XXXIII L. II s. III d. } \\ \text { Recept muable, } & \text { CIIII }^{\mathrm{xx}} \text { V L. V. s. } \\ \text { Recepte des mines } & \text { Néant } \\ \text { Resve, } & \mathrm{II}^{\mathrm{M}} \mathrm{V}^{\mathrm{C}} \text { Livres } \\ \text { Seaux \& greffes } & { }^{\mathrm{C}}{ }^{\mathrm{IIII}}{ }^{\mathrm{XX}} \mathrm{L} .\end{array}$

With these inscriptions, Nicolay explicitly and stylistically distinguished political authority (marked as noble and legal) from commercial life (marked as mundane practice), separating them as traditions of reasoning and as social worlds. The choice of inscription assigned social and institutional qualities to the measures.

Vernacular roman numerals continued to distinguish legal and official matters from mundane ones into the seventeenth century. They were used infrequently, but precisely because of this, became tokens of extraordinary authority, marking nobility, the classical heritage in politics, or the moral and legal authority of rulers (Lemarchand 2010). They can help us trace in subtle detail how Colbert's administration used public documents to engage low-ranked experts in territorial politics, while affirming noble superiority in governance.

\section{Numbers and cultural politics}

Scholars in science and technology studies have already argued that mathematical systems and computations are cultural forms with political significance (Becker and Clark 2001; Bowker and Star 1999; Porter 1995; Rosental 2008). But scholars have not paid much attention to the layers of cultural indexicality that have helped to make numbers important to administrative modernization. We know from Porter (1995), Epstein (2007), and Bowker and Star (1999) that categories for counting are themselves cultural and political forms. We also know from Latour and Woolgar (1979) that written numbers can be immutable mobiles with the capacity to coordinate and facilitate "action at a distance" (Latour 1987). We understand from Porter (1995), Bourguet (1989), and Leibler (2008) that statistics embody conceptions of power, and provide models of social, commercial, and regional relations that shape political orders. We learn from Becker and Clark (2001), too, that numbers can be "little tools of knowledge," contributing to the depersonalization and extension of administrative power. And we know from Porter that trust in numbers has historically helped to make states powerful (Porter 1995). By studying vernacular roman numerals in seventeenth-century France, we can see how

\footnotetext{
${ }^{8}$ See Nicolay (1881). This tradition of counting is described in the Larousse Trois Volumes, Paris: Librairie Larousse, vol. 3, pp. 366-367.
} 
documents could help configure a more modern and effective administration with marks of traditional forms of authority. ${ }^{9}$

Vernacular roman numerals took on even more cultural significance when Colbert and his petit academie started promoting France as a New Rome, destined to restore the heritage and glory of ancient Gaul. This political vision was touted in propaganda, embedded in the artwork and gardens at Versailles, and used as a symbol of French political rebirth during the young king's marriage (Mukerji 2010a). Peter Burke has trivialized this cultural program under Louis XIV as ineffective propaganda (Burke 1992, pp. 125-136). But while ridiculed by France's neighbors, the image of the New Rome became quite effective inside the kingdom, where Colbert was making France seem more Roman with works of neo-classical architecture (such as Perrault's colonnade of the Louvre), infrastructural engineering projects on the scale of the ancients (such as the Canal du Midi), and spectacles in the king's gardens evoking classical culture (such as the divertissements at Versailles) (Goldstein 2008, pp. 44 64,78-98; Mukerji 1997, pp. 203-223, 2009a, pp. 60-63, 2010a)

Representations of France as Rome helped to fashion a conception of French character, heritage, and destiny that made sense of the pursuit of logistical power. Building a great infrastructure would make the kingdom more like ancient Gaul (Mukerji 2010a). This vision of material improvement, using natural knowledge, was meant to be an expression of historical destiny for the descendents of Gaul. It legitimated state activism with a conservative conception of cultural revival. In the political culture of the New Rome, new state agents were instruments for bringing France its ordained glory, impersonal servants for restoring classical grandeur to the land. This political imaginary gave a new layer of significance to vernacular roman numerals as symbols of the future as well as reminders of past forms of power. As French and Roman in form, they were instantiations of a New Rome, traditional symbols of political power now standing for the legitimate empowerment of the French state.

By the seventeenth century, vernacular roman numerals routinely were comprised of lower case roman numerals with superscripts for units. The inscription, LxiiC iiiii $^{\mathrm{C}} \mathrm{xiv}^{\#} \mathrm{xvii}^{\mathrm{s}}$, for instance, stood for sixty-two thousand, four hundred and fourteen French pounds tournois or livres (\#), seventeen sols (s). Livres and sols were French monetary units. The superscript, 9), looked like a "g" but actually meant "m" or "em," standing for mille, ${ }^{10}$ the French world for thousands. "C" stood for cent, or the French word for hundreds. In Hindu-Arabic numerals, the number would be written as 62,414 livres 17 sols.

The French vernacular in these superscripts referenced French words for units: milles, cents, etc. But these superscripts also stood for French units of measurement,

\footnotetext{
${ }^{9}$ The use of vernacular roman numerals by the administration in seventeenth-century France seems to contradict Porter's argument that standardized calculations and measures were part of the formation of the modern state - abstract tools of impersonal power. But Porter was right that building a modern state required a shift in modes of calculation. The shift simply had two distinct moments: one, a shift of recordkeeping from families to the administration, and second, the standardization of numbers. In both moments, the point was to make records trustworthy, but in the first, this was accomplished by endowing them with marks of personal authority - signs of nobility or natural virtue - while in the second, trustworthiness was achieved by a standardization that made numbers seem autonomously "true" (Porter 1986, 1995).

${ }^{10}$ This abbreviation also resembles one sometimes used for "en," but given its use here, it is more likely that it was a form of "em" or "m."
} 
such as monetary units (\# and s) and twenty ( $\mathrm{xx}$ ) as a unit of counting. Using superscripts this way highlighted the French elements of the numerals, pointing to the political import as well as the cultural roots of the system.

The French vernacular used in this system was not a neutral element of the inscriptions. It spoke to the power of French-speaking monarchs over non-French speaking subjects. Vernacular roman numerals symbolized and evoked a pattern of internal colonialism within the kingdom, while simultaneously cloaking it in the common heritage of Rome (compare to Hechter 1975, pp. 47-78; Mukerji 2009b). It is not surprising in this context that numbers written in vernacular roman numerals were often repeated in French words on official documents, where they reinforced the legal power of the monarch with his vernacular. Particularly in non-Frenchspeaking areas at the heart of Roman Gaul, these forms of inscription carried deep political significance (Mukerji 2009b). ${ }^{11}$

To look more closely at how vernacular roman numerals were used as part of official documents to engage experts in territorial projects but defend the principle of nobility, I first turn to Colbert's forest reform, then his correspondence, and finally some documents pertaining to the Canal du Midi. This series of cases illustrates a range of ways paperwork was used to legitimate and deploy a new kind of intelligence in the state and develop more impersonal means of administration, while denying fundamental change in the patrimonial system of power/knowledge (Mukerji 2010a).

\section{Private papers and public documents}

The extensive use of public records under Colbert was partly a means to counter the knowledge practices in the patrimonial system that had previously kept information from the king. In patron-client relationships, the flow and amassing of information mattered, secrets being important assets and a currency of social exchange. Kettering (1988) has demonstrated how information was used in the formation and maintenance of patrimonial clienteles. Concomitantly, monopolizing information in this system was a way to maintain autonomy and gain personal advantages over others (Bourgain and Hubert 2005, pp. 331-334; Lanham 2002, pp. 13-16, 251252; Lemarchand 2010)

Before Colbert's administration, official paperwork was often managed by nobles or high-ranking clergymen that served in local courts, political bodies, tax collecting groups, and other areas of officialdom (Beik 1985, pp. 18-49,77-97; Kettering 1988, pp. 152, 169, 225, 227; Mousnier 1979, pp. 627-656; Murat 1980, pp.143147). They controlled what was written down, what was circulated, and what was reported to the king. (That is why Catherine de' Medici needed Nicolay to copy and send to her information about Lyon (Nicolay 1881)). Nobles used archives as

\footnotetext{
${ }^{11}$ In Occitan, the numbers eighty and ninety have their own words, and are not calculated from base twenty like quatre vingt and quatre vingt et un. So, vernacular roman numerals were "foreign" forms of inscription that needed to be translated through the language of the northern monarchy. In this sense, they were overtly political inscriptions written in a language of authority. Vernacular roman numerals also conveyed an epistemic superiority much like learned Latin and were esoteric modes of communication, standing for aristocracy. Compare to Ong 1982.
} 
institutional memory for their actions as officials, and kept the papers that defined blood lines and hereditary rights to land and offices, documenting births, deaths, and marriages that affected succession. Papers were personal or regional assets with which local courts and ruling bodies asserted patrimonial powers, so Colbert's efforts to turn them into impersonal tools of state governance was a threat to extant social processes of power, turning patrimonial traditions of paperwork to the advantage of the state (Beik 1985, pp. 130,155; Froidour 1899, pp. 18-19; Kettering 1986, pp. 10, 65; Lemarchand 2010; Murat 1980, pp. 143-147).

The minister did not start out trying to do this. But soon after Louis XIV ascended the throne, Colbert learned that nobles were hiding illegal activities from the king and holding onto the records that could prove it. He had initiated a study of French forests to assess the state of French timber reserves and locate stands of trees appropriate for ship-building. He asked the ruling elites officially charged with managing French forests to provide the information. Many refused or lied, withholding the papers that showed the officials had been privately selling timber. Angry about the deceit and usurpation of the king's forests, the minister began a more aggressive reform, checking not only the condition and extent of the trees, but also the papers pertaining to land parcels, timber sales, and forest rights (Froidour 1899, pp. 9-19; Mukerji 2007b, 2009a, pp. 26-27).

Colbert's foresters drew up plans of each parcel of woods, noting the types of trees and their condition, but now they also did systematic interviews with locals, studied maps and papers related to the forests, and gathered family and official documents from nobles. In doing the work, they exercised circumscribed but powerful jurisdiction, following precise steps to get the necessary information. They walked the forests and drew up diagrams using measurements with arpent chains, each link of which was a standard unit. For the interviews, they used printed forms to guide their questioning. The printed protocols left blanks for naming the place under study, the people being interviewed, dates of the study, and rights and uses being claimed and examined (Froidour 1899, pp. 9-19; Mukerji 2007b). Importantly, the names of some foresters themselves were printed in the forms, defining their jurisdiction over the matters at hand.

After the interviews or forest surveys were complete, the foresters wrote exterior summaries of the contents, and those of higher standing among the reformers signed and dated the documents to bear witness to the words and measures recorded in them. The signatures on the outside of the documents were often accompanied by dates written in vernacular roman numerals (compare to Joyce 2009; Portuondo 2009).

Colbert's foresters were, on the one hand, turned into impersonal functionaries only filling out forms and making maps with standard chains, but they were also actors with enormous jurisdictional power over the forests and those who used them. They assessed woodlands even when faced with armed resistance from local nobles because they were charged by the king to make their own measures. They ignored what local elites said about the forests (implicitly denying the virtue of the noble word), and instead used old maps and local testimony to determine patterns of deforestation. In addition, they substantiated titles, legal standing, and hereditary claims to lands with papers they studied and copied. Finally, they fined and taxed even nobles who misused the forests, and set up new courts to judge abuses that 
were restricted from seating as judges those that had contributed to the problem. In this way, the administration made the governance of forests a matter of impersonal public policy, not individual will or family inheritance (Froidour 1899, pp. 18-19; Mukerji 2007b; compare to Murat 1980, pp. 143-147).

\section{Natural virtue and official correspondence}

Letters between Colbert and his higher-status correspondents, officers of the crown and noblemen acting as his agents, often used vernacular roman numerals, employing them in dates as a polite and official form of address. These inscriptions conveyed the authority of the signatories and the veracity of the content. The practice was particularly prevalent among men who bridged social worlds: brokers such as Colbert, or men of rank acting as experts, such as the Chevalier de Clerville. These inscriptions claimed standing for the signatories in situations where their authority could be problematic, using a form of address associated with traditional noble authority to manage potentially "polluting" territorial projects (Kettering 1986, pp. 40-66).

We can see some examples of the practice from a register of Colbert's correspondence from 1669, containing letters about roads, bridges, mines, and other infrastructure. The dates on letters in the register were sometimes written in HinduArabic numerals and sometimes written with vernacular roman numerals, making clear that the scribe who made the register was not determining the style for all the letters (Colbert 1669).

Writing dates with roman numerals might seem a trivial detail, but not in this period of humanist culture. From the Renaissance, classical knowledge had become a marker of "natural virtue," a sign of learning and a desire for truth that marked a nobility of spirit (Mukerji 1997, pp. 19-20). Dates with roman numerals, as we see in more detail below, indexed both the Roman calendar and official records, so their use subtly referenced a degree of learning and credibility.

These symbols of office were all the more important in this period when men without high rank started to hold high office. Colbert himself was from a family of textile manufacturers, and he faced problems of credibility (Murat 1984). He exercised authority in the name of the king, of course, but as a broker, his word had to be independently trustworthy, too, carrying the crédit to enter into alliances with others (Kettering 1986, pp. 43-44). The problem was that only those with noble standing were considered men of their word. So, Colbert had to prove that he had the inner nobility of spirit to be trusted, and he did this by displaying his "natural virtue" through learning (Mukerji 1997, pp. 19-20). Dates written in vernacular roman numerals were a perfect vehicle for this because they were modest, not claiming too much attention. They still displayed knowledge of the Roman calendar and conveyed the power the ancients associated with it.

Months, particularly September through December, were the most frequently written in vernacular roman numerals because they most clearly evoked the Roman calendar. The date for December (decembre in French), the month Colbert most often represented with roman numerals, was written as $\mathrm{x} .^{\text {bre }}$, referring to the tenth month in the Roman calendar. The early Roman or Pre-Julian calendar was lunar, 
and made up of ten months with December as the last month. The twelve-month Julian calendar, developed during the period of Julius Caesar, added the new months of January and February after December, keeping September to December the seventh to tenth months. But the Gregorian reform of the calendar in 1582 changed this, placing January and February at the beginning of the new year, so the New Year would start just after the birthday of Christ. This pushed December back to the twelfth month of the cycle. The resulting mismatch between the words for the months, September, October, November, and December, and their placement in the twelve-month cycle made the representation of December as $\mathrm{x} .{ }^{\text {bre }}$ a double reference to classical culture - both the numeral system and the calendar (Duncan 1998; Menninger 1969). The months September through November were also frequently signified as vii ${ }^{\text {bre }}$, viii ${ }^{\text {bre }}$, and $\mathrm{ix}^{\text {bre }}$, since the roots of the words for the months also stood for numbers. The Chevalier de Clerville even sometimes represented them in Hindu-Arabic numbers as $7^{\text {bre }}, 8^{\text {bre }}$, or $9^{\text {bre }}$, still referencing the names of months in the Roman calendar even without vernacular roman numerals.

The men of lesser rank and education who served Colbert as brokers or contracted agents did not use vernacular roman numerals in dating their letters. They did not claim their authority through nobility of spirit. But their social superiors, men like Colbert, the Chevalier de Clerville, intendants in the provinces, and others connecting Versailles to territorial projects, used these inscriptions to locate their authority not in their material effectiveness but in their moral standing as gentlemen.

\section{Roman law and legal paperwork}

Legal papers were another place where vernacular roman were frequently used, and were one of the sites where vernacular roman numerals had traditionally been required (Lemarchand 2010). Local and regional tribunals and councils were staffed (mainly) by officials of noble station, who not only exercised the power of the word, but also were expected to apply roman law in their judgments. So, paperwork with roman inscriptions multiply referenced and evoked the cultural genealogy of legal practices in France through the seventeenth century.

We can see the surprising potency of inscriptions as marks of legal authority in themselves from a legal case brought by Riquet, the entrepreneur for the Canal du Midi, against one of his subcontractors for the canal, Immanuel d'Estan. The question in the legal dispute was who should shoulder the financial burden for costs for the work that exceeded the contracted amount (de la Feuille 1678). In documents accounting for monies paid and monies owed, one might have expected the figures to be written in Hindu-Arabic numerals, but they were written in vernacular roman numerals to give them legal standing. This was not only conventional practice, but a way to define the assessment as a matter of law.

The entrepreneur was (perhaps surprisingly) the judge for the case. Riquet had been given the land for the canal as his domain in the contract for the project, making him legally sovereign over the area. But he was not considered a man of real nobility of blood or spirit. So, he turned to a man of natural virtue sent to Languedoc as a supervising engineer by Colbert, the sieur de la Feuille, to write up the case for him. The latter created an official memoir for the court, detailing the dispute between 
Riquet and d'Estan that presented the debate and relevant figures in vernacular roman numerals.

The "Memoire pour Mr le President Riquet" by la Feuille described what d'Estan had done, how Riquet responded, and the course the dispute over time (de la Feuille 1678). It included figures claimed by d'Estan and the amounts Riquet was willing to pay (de la Feuille 1678). The first receipt from d'Estan or "premierement recepte" was written as $\mathrm{iiii}^{\mathrm{xx}}{ }_{\mathrm{v}} \mathcal{G} \mathrm{v}^{\mathrm{C}} \mathrm{iii}^{\#} \mathrm{v}^{\mathrm{s}}$ and some additional deniers. This amount was granted by Riquet and written in the column to the right. The second claim of iiii ${ }^{\mathrm{C} \#}$ or four hundred pounds was also granted. The sum of these two receipts was then written out in French, giving final authority of "the word" to the measure (Anon 1671; Conseil d'État 1671; de la Feuille 1678). On the basis of this document, filled with figures written in a form appropriate to the exercise of law, Riquet was able to issue judgment against d'Estan, relying on La Feuille's words and numbers to give the decision legal standing.

The original contract with d'Estan was not written with vernacular roman numerals because it was an agreement about work to be done, but the legal case alleging violations to the contract (changing the design of the bridge and its costs) had to use vernacular roman numerals. The type of inscription was a way of underscoring the moral and legal standing of the numbers, and was particularly useful in distinguishing between what was negotiable and what was not.

\section{Territorial contracts and administrative modernization}

The Canal du Midi provides an example of how contracted territorial projects were managed with paperwork, both extending state powers into the countryside through engineering and constraining the experts who changed the landscape with contractual stipulations and verifications. It is also an interesting case because the entrepreneur, Riquet, was a tax farmer who had gotten rich on contracts with the government. As Weber noted, tax farming, or the contractual outsourcing of tax collection to private individuals, was an ancient practice that embodied many characteristics of modern bureaucratic officialdom. Tax farmers agreed to provide the treasury with an amount of revenue and could pocket the rest of what they gathered. As a rich tax farmer who could use some of his own funds in a speculative venture, Riquet was exactly the kind of man Colbert wanted to build the New Rome, but to keep from gaining personal power. So, the minister gave Riquet little discretion in the design of the canal, but gave him the massive authority to change the infrastructure of Languedoc.

Given a highly specified technical job to fulfill, Riquet functioned more as a nascent technocrat than a traditional official in his work on the Canal du Midi. The entrepreneur agreed to provide a canal for a stipulated amount of money, by a particular date, and with designated features, and would have the right to profit from it when it was done. The agreement gave Riquet nominal noble status and the land for the canal as his domain, but did not give him personal powers of office. He was only to fulfill the contract as stipulated, not build the waterway as he saw fit (Arrest 1666). In this sense, he was made a "modern" official with 
jurisdictional rather than personal authority, and with prescribed duties he was obliged to fulfill (and he resented this) (Mukerji 2009a). ${ }^{12}$

The contract for the Canal du Midi itself and papers used to revise it illustrate in fine detail how the administration used paperwork to bring into government service not only financiers like Riquet, but even more discredited contributors who served as subcontractors and indigenous experts in pursuit of the New Rome. These files reveal how Riquet was subjugated to his social superiors, and how this subjugation was used by the state to reaffirm patrimonial authority and draw local nobles into state projects.

The Canal du Midi clearly needed careful political handling because the project required land that was indemnified by the king and taken from local elites. There were also disputes over financing between the king and the États du Languedoc, the local tax institution representing those of superior rank in the province. The men of the États wanted to stop the project; Louis XIV wanted them to help pay for it. That set up a struggle of authority between the crown and the ruling elites of Languedoc that neither wanted to lose (Mukerji 2009a, pp. 61-62). It was a battle waged with paperwork. Documents surrounding the Canal du Midi became sites where political legitimacy was problematic, measures were matters of contention, and where some numbers were endowed with higher authority with vernacular roman numerals.

The French elements of vernacular inscriptions (both numbers and words) on contractual paperwork for the Canal du Midi had particular meaning in Languedoc. The people of the region spoke d'Oc or Occitan rather than French, and lived in social worlds culturally and psychologically distant from the northern court. Even nobles in the province were notoriously independent of the crown, traditionally simply ignoring demands arriving from Versailles. Many were Huguenots with little respect for a Catholic king that they saw as corrupt and immoral (Holt 2005:99-101). ${ }^{13}$

In this context, the canal project became a test of political finesse in which textual practices mattered. Since documents from Versailles written in French did not necessarily have political purchase in Languedoc, the most important numbers on papers for the Canal du Midi were marked as legally binding obligations with vernacular roman numerals, linking the project to the New Rome and reaffirming patrimonial authority as a principle of governance with the king in charge.

\section{Jurisdiction and obligation}

We can see better how the contract system was used to manage territorial work by examining three cases where Riquet asked to change the contract for the Canal du

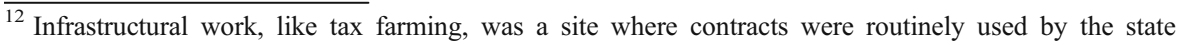
because the treasury could not afford the work itself, and the projects required technical expertise that was rarely cultivated by traditional officials. Contracts allowed experts and entrepreneurs without social rank to take on these projects, bringing elements of political modernism into French administration (Weber et al. 1978).

${ }^{13}$ To defend their autonomy, the elites in Languedoc violently opposed building a canal for the king in their province. Louis XV, for his part, not only insisted on the canal, but also demanded that the local tax authority, the États du Languedoc, pay for much of the work. Contentious politics led to a proliferation of documents on contractual matters: edicts, stipulations and specifications, technical inspections, and assessments of work done and to be done. Vernacular roman numerals were political weapons in this textbased war, standing for law and legitimate government where these were problematic.
} 
Midi, once to alter the route for the waterway, once to rewrite the technical specifications for locks, and once to continue the canal from the Aude River to the Mediterranean.

The first, dated 1671, was a response to an offer by the city fathers of Castelnaudery to give Riquet money to divert the canal and build a port beneath the hillside site of their town. The États du Languedoc, being firmly opposed to the Canal du Midi, were withholding funds from Riquet, trying to starve the project. So, the entrepreneur wanted to reroute the canal and take the money, but this required approval of the Conseil d'État. Colbert took the proposed change to the Conseil where it was discussed and approved, and where thirty thousand pounds from the treasury was also approved to help defray the costs (Conseil d'État 1671).

The decision from the Conseil was written stylistically to try to get Riquet some money. The figure, " $\mathrm{xxx}$ C)\#" or thirty thousand pounds, was written with vernacular roman numerals, marking the release of tax funds as a matter of obedience to the king and his council. The decision of the Conseil d'État was also formally conveyed to the États by a gentleman and inspecteur général for the canal, the Sr de Contigny, who dated the document with vernacular roman numerals: "xxiiiie dud' Mois de May" or the 24th of May, underscoring the authority of the decision (Conseil d'État 1671).

A document from 1676 illustrates another way legal and royal authority was marked in inscriptions. Riquet wanted to change the specifications for locks near the Garonne River. The walls of the original locks had started to collapse, and Riquet wanted to rebuild them as double or triple staircase locks with each lock shallower and less prone to collapse (Mukerji 2009a, pp. 81-82). The new design worked, but the staircase locks entailed expenses and construction practices beyond those specified in the contract. The 1676 document agreed that the new locks were necessary, but still considered whether Riquet needed to fulfill the contract within the original budget.

The manuscript used the size of the handwriting to differentiate technical issues from legal ones, legal reasoning being written in a large script, and technical discussions in a small hand. This format not only separated legal reasoning from technical issues, but also implied that legal obligations had priority over technical ones. The same distinction was made with numbers where the document referenced the contract for the Canal. The authors specified the relevant stipulations in the contract with vernacular roman numerals (ACM uncataloged).

A third document from the Conseil approved extending the Canal du Midi from the Aude River (the end of the first enterprise) to the Mediterranean (ACM 07-05). In this document, the numbers describing technical specifications for the work were written out in French, and costs associated with them were written in Hindu-Arabic numbers. But at the end of the manuscript, the summary of the amounts being appropriated from the treasury used numbers written in vernacular roman numerals.

In all three documents, the Conseil d'État defined the financial and legal obligations of those serving the king. They formally subordinated Riquet to the words of the contract, and pushed for obedience to rulings from the Conseil by the États du Languedoc. The different forms of address helped to reaffirm nobility as a principle of power, but the decisions by the Conseil d'État also turned requests by a nascent technocrat into the will of the king, 


\section{Layers of authority in public documents}

Looking at the uses of vernacular roman numerals in public documents during Colbert's administration provides interesting insight into the political culture of public administration during this period but also raises the question of how inscriptions worked in the formulation of public policy. To address these concerns, I turn now to another set of documents for the Canal du Midi: the original contract as published in 1666 and a set of formal assessments from 1683 to 1684 that determined how to fulfill the contract. Although they do not use vernacular roman numerals, they constitute "dossiers" rather than single papers, and allow us to examine more of the literary practices used to separate and align experts and officials in the formation of administrative policies.

Most documents from reign of Louis XIV that addressed territorial policies were in fact bundles or nests of papers that grew as they circulated. Different stakeholders and experts would examine and comment on a dossier, their documents joining the bundle of papers as it snow-balled in size with new layers of logistical and strategic reasoning. These bundles became units of power/knowledge in the sense that they included reasoning about both political and technical concerns related to a given problem of policy. Each layer tended to emphasize either technical knowledge or political authority, but the dossier aligned them in policy decisions that directed and gave coherence to administrative action.

All the documents concerning the contract for the Canal du Midi that we examined in the previous section of this article were in fact dossiers. They were products of information flows between technical and political experts who collaborated but remained socially distant. In this section, I look more closely at dossier formation as the mechanism for organizing thought and action around territorial governance, drawing on both official procedures and material measures to pursue the New Rome.

Both the dossier for the contract and the papers defining its completion help reveal in different ways how layers of papers in public documents built off one another: quoting earlier reports or decisions, gathering commentaries, adding verifications to assessments, and picking up signatures to authorize proposed actions or to verify facts. Creating layers of papers in files allowed strategic and logistical reasoning about policy issues to be kept distinct but placed in conversation, addressed by different people but focused on common problems. Dossiers themselves also used differences in handwriting and fonts to distinguish kinds of authority and expertise in ways elsewhere marked with vernacular roman numerals ${ }^{14}$ (1667). They demonstrate, in other words, how the administration could build a system of distributed cognition or collective learning to serve the state, using the circulation of public documents to manage the social risks of bringing new ideas and actors into the government.

\footnotetext{
${ }^{14}$ We have already glimpsed bundling practices the 1676 discussion of lock specifications that included a copy of the original contract. They were also visible in the maps, interviews, and attached documents used in the forest reform. So building dossiers was common to the archiving practices that both included and did not include papers with vernacular roman numerals.
} 
The "Arrest d'Adjudication des Ouvrages a Faire pour le canal du communication des deux mers, Oceane \& Mediterranée en Languedoc" (1666) a published version of the contract for the Canal du Midi, had seven sections, each addressing some political or technical issue. The document was published so it would serve as an official statement of public policy, and used differences in font to distinguish kinds of authority. Decisions carrying the weight of law and words of the monarch were marked with italics, while historical narratives and agreements were written in plain text. The result was a policy statement that both conveyed and distinguished the forms of reasoning and kinds of authority behind the policy (Arrest 1666). ${ }^{15}$

The document began with two extracts from the register of the Conseil d'État. Both of these had titles in italics to underscore their standing as expressions of authority. The information in the sections, however, was marked as mundane with plain text. The first section was short, and simply introduced the canal, presenting it as the king's will and a project awarded to Pierre-Paul Riquet (Arrest 1666). The second was large, and had two parts: the devis (the estimate for the project with specifications for the work) signed by the Chevalier de Clerville, and a statement of the king's approval for these specifications (signed by his steward who presumably knew what they meant).

The devis specified where the canal should go and how it should be built, explicitly prohibiting Riquet from making any changes to the plan without permission, and requiring him to ameliorate any problems at this own expense. The devis was drawn up and signed by the Chevalier de Clerville, whose signature gave noble and expert credibility to the technical content and policies. His devis had standing, too, because it was mainly a compilation of decisions made by a commission of notables that Clerville had headed to study the original plan. Following Clerville's signature, there was a section of the Arrest with king's official approval of the devis, signed by the financier and steward of the king's household, Bechameil (Arrest 1666).

If the first three parts of the Arrest focused on technical stipulations for the canal, the next three sections described its political authorization. The narrative began with the commission led by Clerville. Once these gentlemen had studied the route and were assured that there was enough water to supply the canal, they gave the project their approval. They produced a devis that was published and put up to bid, and Riquet won the bid, signing his assent to the terms of the devis. The next section reviewed the terms of the contract, using headings for each stipulation to emphasize the formal commitments on both sides. Finally, Bechameil testified that these agreements had been discussed by the king in his economic council, where they had been approved. Again, he signed for the king (Arrest 1666).

The 1666 Arrest ended with a long statement in italics from the king himself, proclaiming the value of the project for the kingdom and particularly the province. He called upon local notables in Languedoc to help Riquet realize this grand enterprise. Then he signed and dated the document, giving it royal sanction (Arrest 1666). The technical logics of the document and the political calculations of the contract were turned into monarchical will.

15 The Etats also signified their registration (acceptance) of the project with italics. 
Italics in the Arrest were used similarly to vernacular roman numerals in other documents. They helped to mark the moral and legal foundations of the contract itself, and defined its execution as a form of obedience. The king and his council were presented here, too, as the ones in charge of restoring nobility in France and making the kingdom more Roman with great works. This was not Riquet's canal, but part of the king's grand design.

Most nests of paper for the Canal du Midi were similar in evoking both technical and patrimonial authority in the articulation of policy, creating dossiers that linked knowledge to power for territorial governance. We can see how technical information was circulated and incorporated in policymaking documents by comparing the set papers from 1683 to 1684 that "verified" what was needed to finish the Canal du Midi. The technical study, "Memoire de ... l'estimation des reparations a faire" (1683) was co-authored by two trained engineers for the canal: the sieur de la Feuille, and a Jesuit engineer, Père Morgues or Mourgues - both experts and men of natural virtue. They personally inspected the canal, assessed its problems and offered solutions to them (with estimated costs). The upper portion of their document was set out in columns, each for a major feature of the canal needing repair. Each "expert" presented an independent cost estimate, but they collectively developed the technical diagnoses and solutions (la Feuille and Mourgues 1683).

The official document by the intendant, d'Aguesseau (1684), was a "procez verbal," testimony rather than a legal contract, but still published as policy. It described what the Riquets needed to do to fulfill the contract for the Canal du Midi. Technical assessments and recommendations in the published policy were attributed to Morgues, clearly distinguishing the Jesuit's expertise from the intendant's policymaking (la Feuille and Mourgues 1683). The political authority for publishing the policy was attributed to the Conseil d'État. D'Aguesseau said he was responding to a 1684 demand from the Conseil based on an edict dated March 14, 1682. The 1684 procez verbal, then, distinguished and evoked three types of authority: the authority of Conseil d'État (or king), the authority of the intendant (a royal official), and finally, the technical authority of la Feuille and Morgues (experts). The policy was made credible on technical grounds and legitimate as a political action because of the layers of authority and knowledge invested in the document. Using inscriptions to draw together distinct kinds of knowledge and authority, technical recommendations became a matter of law and political obligation to the king (d'Aguesseau 1684; la Feuille and Mourgues 1683).

As a practice of power, this way of building up official dossiers did a lot of social work. It served as a supervisory technique for the administration, circulated policy decisions among interested parties, provided technical bases for collaboration, and aligned technical logics with political ones to yield territorial policies. Circulating files allowed groups with very different logics of power and forms of reasoning to collaborate and secure for the administration an intelligence about territorial governance that was profoundly effective. The persons who would sign off on a document could vary, but technical decisions always required some ratification and commentary by an authorizing signature. And in these ways, dossiers were to form administrative patterns of distributed cognition and collaborative reasoning about policies (Hutchins 1995; Mukerji 2009a). 
The dossiers that linked experts and officials intellectually around problems of territorial governance while keeping them politically and socially apart. They were impersonal tools of power, too, yielding modern forms of political servitude, and they were (each in their own way) instantiations of the knowledge regime for territorial governance (d'Aguesseau 1684).

\section{Conclusions}

Tracing the use of vernacular roman numerals in official documents from late seventeenth-century France provides a surprisingly rich view into the workings of power during French state formation, revealing how authority and knowledge were managed for political effect with written inscriptions. Vernacular roman numerals (like their textual counterparts) marked patterns of submission and authority among actors in the government. They were used in the struggle between the provinces and king, defining patrimonial allegiances and conditions of obedience. They were used to subject Riquet to the Conseil d'État, subordinate d'Estan to Riquet's legal judgment, and submit the États du Languedoc to the king's will. And above all, they visibly marked the on-going significance of patrimonial authority in documents that fueled territorial projects with a new knowledge regime.

The design of documents, particularly their uses of vernacular roman numerals, also offers subtle insights into the cultural dynamics of administrative modernization during this period of early state formation. We can see how the cultural legacy of Rome was evoked in administrative documents used to build a New Rome, and was used by high-ranking administrators in dating practices as evidence of their moral authority to restore the kingdom to its proper glory. Vernacular roman numerals were employed as well by agents claiming documents from noble families, and conversely used to reaffirm noble superiority as the fundamental principle of power. Most of all, they were used to organize and give legitimacy to the circulation of natural and tacit material knowledge through government projects, allowing the state to wield a massive logistical capacity through paper-based practices.

That Colbert would turn to logistical policies and literary practices should not be a surprise in an educated man from his period. Humanist scholars had been studying and translating Roman writings on logistical practices and natural knowledge: architecture, natural history, estate management and other practical arts. Italian engineers were already using classical ideas to design new military installations, infrastructure and drainage projects. The French government followed suit, but paid even more attention to Roman agronomy, trying to restore the French countryside devastated by the wars of religion. French writings on the subject provided the intellectual bases for seventeenth-century works on political territoriality that finally influenced the administrative policies of Colbert (Long 2001, pp. 16-71; Mukerji 2002).

But while ancient writings could provide the intellectual and cultural tools for infrastructural projects, the ancients could not provide social precedents for territorial politics. Colbert could not use soldiers and slaves as laborers as the Romans had done. But France had other groups with comparable skills and a similar lack of independent power: peasants, artisans, civil engineers, and entrepreneurs. They 
became the architects of the New Rome, working in highly constrained, task-driven, paper-based projects.

The new experts in material matters interacted with brokers more than courtiers, and were governed by paperwork more than personal influence. They entered into contractual forms of governance, creating a dual system of power, but not the parallel set of officials usually associated with this administration. They brought to government a different kind of power/knowledge, organized around logistics and subjugated knowledges. Appointed officials still dominated patrimonial politics and thought strategically about interpersonal advantages, but low-status agents brought ideas that were used to transform the state. The two social groups were kept apart, but their logics met in dossiers where information about the earth was circulated, viewed in relation to law or political interests, and turned into public policy.

Serving as faceless agents of the state in a paper-based system of jurisdictional governance, the contractors with the administration became Weber's modern servants of standing. Providing the collective intelligence for state projects, they helped to give this institution new powers over the kingdom and its people. The resulting state was less a modern "apparatus" of power than a set of paper-based practices of contractual governance, accumulating and deploying natural knowledge to alter strategically material life in the name of the New Rome. What made the administration more effective in this moment was not its social orderliness, but rather its intellectual capacity - the distributed knowledge regime built at the intersection of two (mostly) non-overlapping networks of experts/officials with distinct intellectual cultures.

The risks to the state of exercising logistical powers through low-status experts were lessened in this political context because officials and experts were socially far from each other. Men without rank in seventeenth-century France-even ones with great fortunes like Riquet-were systematically disdained by nobles, so they could gain few allies and acquire little independent power as officials. But in other historical circumstances, Weber's bureaucracy may have been a necessary means for containing logistical power as a tool of state governance. Where the gulf between ranks was less profound and technical knowledge more widespread, it would make sense to assign technocrats to offices without personal discretion and with hierarchical reporting structures to keep them in line. But when Colbert's administration started experimenting with logistical power to build a New Rome, this was not a recognized problem. The first priority was to find the expertise to become more Roman without damaging the patrimonial order, crafting the literary practices of power that would allow technocratic logics and patrimonial concerns to come into impersonal conversation on paper, creating a new and surprisingly effective system of political reasoning through the circulation of public documents.

We already know that in many historical moments and in many different institutions, those with power try to control information and cultivate social intelligence to their advantage. As Foucault made clear, power relations are always and necessarily deeply intertwined with knowledge regimes. Corporations as well as governments have interests in developing and controlling new ways of knowing so they can out-wit their competitors. States gather and use intelligence, and deploy it 
to build policy, weapons and infrastructure. They also develop copyright laws, and American law even extends copyright to corporations, clearly indicating that knowledge regimes and intellectual advantages matter both to business and government.

Weber pointed to the importance of knowledge regimes to state formation when he wrote about files. And Foucault pointed to the political centrality of systems of power/knowledge. Here we can see an example of how a new knowledge regime for territorial governance was formed as a system of distributed intelligence, using the political reasoning of officials and technical expertise of state agents. The intellectual cultures of these groups were kept distinct because their social origins were different, and their ties with the administration were based on different principles: personal relations or impersonal measures of material action. Reaffirming the principle of nobility also drew a deep cultural line between the two groups. But their different capacities for reasoning were joined through the circulation and formation of dossiers, creating an impersonal form of social intelligence based on paper and resulting in public policies.

In seventeenth-century France, bureaucratic modernism and the expansion of state power were fashioned at the intersection of two systems of power/knowledge (patrimonial and territorial) joined in the hopes of making France more powerful by becoming more like Rome. The ancient empire not only provided a model of military prowess, but also technical finesse that Colbert tried to make a hallmark of the regime. He shifted the grounds of French life with engineering as the Romans had done, and sought new expertise to do it. He wanted to empower the king without impinging on the moral authority of patrimonial elites or extending personal powers to experts. So, he created two forms of administration, official and contractual, faceto-face and mediated, and made the administration the center of calculation between the two. The French state became both more modern and effective with bundles of circulating public documents that managed social relations of power and turned technical and political reasoning into policies of territorial governance.

Open Access This article is distributed under the terms of the Creative Commons Attribution Noncommercial License which permits any noncommercial use, distribution, and reproduction in any medium, provided the original author(s) and source are credited.

\section{References}

(1667). Edit du Roy pour la construction d'un Canal du communication des deux Mers, Océane \& Méditerranée pour le bien de Commerce \& autres avantages y contenus. Avec l'Arrest \& LettresPatenes sur icelui, en interprêtation dudit Edit du 7 Octobre 1666. Vol. Archives du Canal du Midi (ACM 03-10). Paris: Chez Pierre Prault.

Anon. (1671). Extrait des registres du Conseil d'Etat. Vol. 11. Toulouse: Archives du Canal du Midi. Arrest (1666) Arrest d'adjudication des ouvrages à faire pour le communication des Mers en Languedoc ... 14 octobre 1666. ACM 3-10.

Becker, P., \& Clark, W. (2001). Little tools of knowledge: Historical essays on academic and bureaucratic practices. Ann Arbor: University of Michigan Press.

Beik, W. (1985). Absolutism and society in seventeenth-century France: State power and provincial aristocracy in Languedoc. Cambridge: Cambridge University Press. 
Bourgain, P., \& Hubert, M.-C. (2005). Le latin médiéval. Turnhout: Brepols.

Bourguet, M.-N. (1989). Déchiffrer la France: la statistique départementale à l'époque napoléonienne. Paris: Editions des archives contemporaines.

Bowker, G. C., \& Star, S. L. (1999). Sorting things out: Classification and its consequences. Cambridge: MIT Press.

Burke, P. (1992). The fabrication of Louis XIV. New Haven: Yale University Press.

Conseil d'État (1671). Extrait des registres du Conseil d'Etat. Vol. 11. Toulouse: Archives du Canal du Midi.

Colbert, J.-B. (1669). Registre contentant les ordres, instructions et lettres expediees par Monsiegneur Colbert, touchant les fortifications des ponts et chausees, canal de communication des mers et mines en Languedoc en l'annee 1669. Archives de l'Ecole des Ponts et Chaussées.

d'Aguesseau. (1684). Procez Verbal de Verification et Estimation des Ouvrages du Canal par M. Daguesseau. Toulouse: Archive du Canal du Midi (ACM 13-11).

de la Feuille, P. ca. (1678). Memoires pour M. le President Riquet. Vol. uncatalogued paper: ACM.

Duncan, D. E. (1998). The calendar: The 5000-year struggle to align the clock and the heavens-and what happened to the missing ten days. London: Fourth Estate.

Epstein, S. (2007). Inclusion: The politics of difference in medical research. Chicago: University of Chicago Press.

Forestié, É. (1893). Les Livres de comptes des frères Bonis, marchands Montalbanais du XIVe siècle. Paris: Honoré Champion.

Foucault, M. (1966). Les mots et les choses. Paris: Gallimard.

Foucault, M. (1977a). Discipline and punish: The birth of the prison. New York: Pantheon Books.

Foucault, M. (1977b). Language, counter-memory, practice: Selected essays and interviews. Ithaca: Cornell University Press.

Foucault, M., \& Gordon, C. (1980). Power/knowledge: Selected interviews and other writings, 19721977. New York: Pantheon Books.

Froidour, Louis de. (1899). Les Pyrenées centrales au XVIIe siècle; lettres écrites ... à M. de Héricourt ... et à M. de Medon. Auch: Impr. et lithographie G. Foix.

Goldstein, C. (2008). Vaux and Versailles: The appropriations, erasures, and accidents that made modern France. Philadelphia: University of Pennsylvania Press.

Haraway, D. J. (1989). Primate visions: Gender, race, and nature in the world of modern science. New York: Routledge.

Hechter, M. (1975). Internal colonialism: The Celtic fringe in British national development, 1536-1966. Berkeley: University of California Press.

Holt, M. P. (2005). The French wars of religion, 1562-1629. Cambridge: Cambridge University Press.

Hutchins, E. (1995). Cognition in the wild. Cambridge: MIT Press.

Joyce, P. (2009). Filing the Raj: Political technologies of the Imperial British state. In T. Bennett \& P. Joyce (Eds.), Material powers: Essays beyond cultural materialism. London: Routledge.

Kettering, S. (1986). Patrons, brokers, and clients in seventeenth-century France. New York: Oxford University Press.

Kettering, S. (1988). The historical development of political clientelism. Journal of Interdisciplinary History, $18,419-447$.

la Feuille, Pons de, and Matthieu de Mourgues. (1683). Canal du Jonction des Mers au mois d'octobre de l'année 1683. Archives du Canal du Midi (uncatalogued).

Laborde, L., \& Guiffrey, J. (1877). Les comptes des bâtiments du roi (1528-1571) suivis de documents inédits sur les châteaux royaux et les beaux-arts au XVI siècle. Paris: Baur.

Lanham, C. D. (2002). Latin grammar and rhetoric: From classical theory to medieval practice. London: Continuum.

Latour, B. (1987). Science in action: How to follow scientists and engineers through society. Cambridge: Harvard University Press.

Latour, B., \& Woolgar, S. (1979). Laboratory life: The social construction of scientific facts. Beverly Hills: Sage.

Leibler, A. E. (2008). Nationalizing statistics a comparative study of the development of official statistics during the 20th century in Israel-Palestine and Canada. pp. xv, 301.

Lemarchand, Y. (2010). Chiffres de finance. In M.-L. Legay (Ed.), Dictionnaire historique de la comptabilité publique 1500-1850. Rennes: Presses Universitaires de Rennes.

Long, P. O. (2001). Openness, secrecy, authorship: Technical arts and the culture of knowledge from antiquity to the Renaissance. Baltimore: Johns Hopkins University Press.

Lynn, J. A. (1997). Giant of the grand siècle: The French Army, 1610-1715. Cambridge: Cambridge University Press. 
Mannheim, K., Wirth, L., \& Shils, E. (1952). Ideology and utopia; an introduction to the sociology of knowledge. London, New York,: K. Paul, Trench, Trubner \& co.; Harcourt, Brace and company.

Meeker, M. E. (2002). A nation of empire the Ottoman legacy of Turkish modernity. Berkeley: University of California Press.

Menninger, K. W. (1969). Number words and number symbols: A cultural history of numbers. Cambridge: MIT Press.

Mousnier, R. (1979). The institutions of France under the absolute monarchy, 1598-1789: Society and the state. Chicago: University of Chicago Press.

Mukerji, C. (1997). Territorial ambitions and the gardens of Versailles. Cambridge: Cambridge University Press.

Mukerji, C. (2002). Material practices of domination and techniques of Western power. Theory and Society, 31, 1-31.

Mukerji, C. (2007a). Demonstration and verification in engineering: ascertaining truth and telling fictions along the Canal du Midi. In L. Roberts, P. Dear \& S. Schaffer (Eds.), The mindful hand: Inquiry and invention from the late renaissance to industrialization (pp. 169-186). Chicago: University of Chicago Press.

Mukerji, C. (2007b). The great forest survey of 1669-1671. Social Studies of Science, 37, $227-253$.

Mukerji, C. (2009a). Impossible engineering: Technology and territoriality on the Canal du Midi. Princeton: Princeton University Press.

Mukerji, C. (2009b). The new Rome: Infrastructure and national identity on the Canal du Midi. Osiris 24.

Mukerji, C. (2010a). The Territorial State as a Figured World of Power: Strategics, logistics and impersonal rule. Sociological Theory, 28.

Mukerji, C. (2010b). The unintended state. In T. Bennett \& P. Joyce (Eds.), Material powers. London: Routledge.

Murat, I. (1980). Colbert. Paris: Fayard.

Murat, I. (1984). Colbert. Charlottesville: University Press of Virginia.

Nicolay, Nicolas de. (1881). Description Générale de la Ville de Lyon et des Anciennes Provinces dy Lyonnais et $d u$ Beaujolais par $N$. de Nicolay. Texte imprimée et annotée par la Société de Topographie historique de Lyon et précédée d'une notice sur N. de Nicolay, edited by A. Vachez. Lyon: Impremerie Mougin-Rousnd.

Nietzsche, F. W. (1990). The birth of tragedy: And, the genealogy of morals. Translated by F. Golffing. New York: Anchor Books.

Ong, W. J. (1982). Orality and literacy: The technologizing of the word. London: Methuen.

Porter, T. M. (1986). The rise of statistical thinking, 1820-1900. Princeton: Princeton University Press.

Porter, T. (1995). Trust in numbers: The pursuit of objectivity in science and public life. Princeton: Princeton University Press.

Portuondo, M. M. (2009). Secret science: Spanish cosmography and the new world. Chicago: University of Chicago Press.

Pynson, R., Praetorius, C., \& Sommer, H. O. (1892). The Kalender of Shepherdes. Vol. I. London: Kegan Pual, Trench, Trübner \& Co.

Rosental, C. (2008). Weaving self-evidence: A sociology of logic. Princeton: Princeton University Press.

Weber, M., Roth, G., \& Wittich, C. (1978). Economy and society: An outline of interpretive sociology. Berkeley: University of California Press.

Chandra Mukerji is Distinguished Professor of Communication and Science Studies at the University of California, San Diego. She is author of Territorial Ambitions and the Gardens of Versailles (Cambridge 1997), From Graven Images: Patterns of Modern Materialism (Columbia 1983), A Fragile Power: Science and the State (Princeton 1989), with Michael Schudson, Rethinking Popular Culture (California 1991), and Impossible Engineering: Technology and Territoriality on the Canal du Midi (Princeton 2009). She is currently studying French views of the Ottoman Empire in the sixteenth century, looking at early attempts at social analysis, historical conceptions of race and dress (the inside and outside of character), and genealogies of Orientalism. 